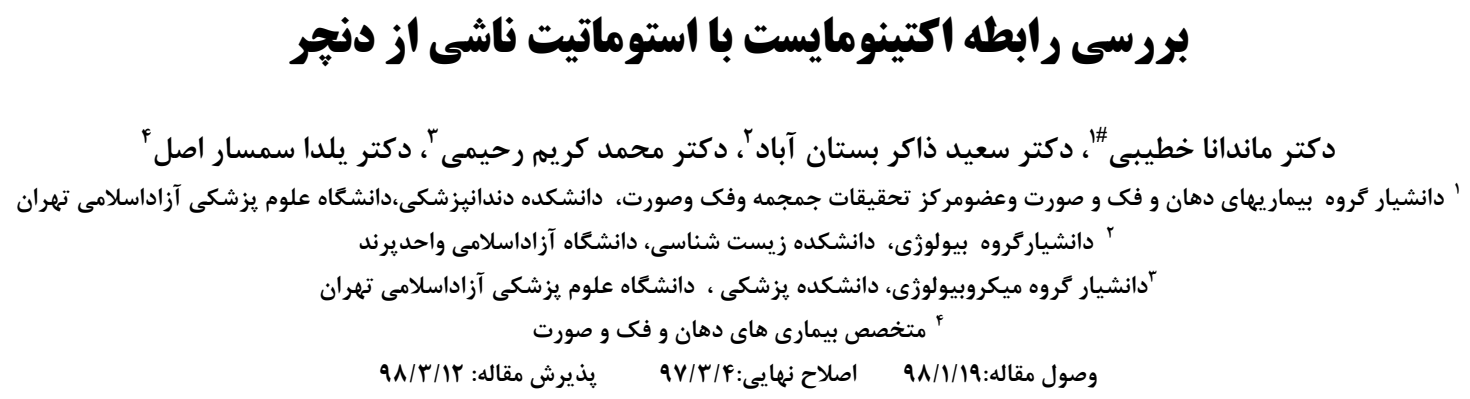

\title{
The relation between Actinomyces and denture stomatitis
}

\author{
Mandana Khatibi ${ }^{1 \#}$, Saeed Zaker Bostanabad ${ }^{2}$, Mohammad Karim Rahimi ${ }^{3}$, Yalda Semsar Asl ${ }^{4}$ \\ ${ }^{1}$ Associate Professor, Oral medicine dept; Faculty of Dentistry; Tehran Medical sciences; Islamic Azad University; Tehran; Iran \\ ${ }^{2}$ Associate Professor, Biology dept; Faculty of Biology science; Parand branch; Islamic Azad University; Tehran; Iran \\ ${ }^{3}$ Associate Professor Microbiology dept; Faculty of Medicine; Tehran Medical sciences; Islamic Azad University; Tehran; Iran \\ ${ }^{4}$ Specialist in Oral Medicine; Tehran; Iran
}

\section{Abstract}

Received: 9 April 2019; Accepted: 3 June 2019

Background \& Aim: Denture induced stomatitis occurs in 24-60 percents of edentulous people who have dentures.Up to now some etiologic factors have been introduced for denture stomatitis but there are some controversies.In some literatures some other microorganisms have been isolated besides candida albicans as main reasons. According to the incidence of denture induced stomatitis and the resistance and recurrence to treatment with antifungal drugs in some of these cases this research was done to evaluate the role of actinomycets in these lesions

Material and methods: In this case control study the samples were collected from 15 persons with removable full dentures without any denture stomatitis and 15 persons with removable full dentures with denture stomatitis lesions. Both groups were matched according to age, gender ، duration of denture wearing ، systemic diseases, oral hygine, smoking,xerostomia, use of medicines and The samples were transported to the lab in thyo culture and incubated in $37 \mathrm{C}$ for 1 week and then transported to Brain and Heart infusion culture .After sample processing for microscopic evaluation for detecting actinomycets ، the results were analyzed with chi-square test by using spss soft ware version 14.

Results: The results shows that 5 of $15(33.3 \%)$ in control group and 11 of $15(73.3 \%)$ in case group were actinomycets positive. $(\mathrm{p}<0.03)$

Conclusions: It seems that, actinomycets can play a role in denture stomatitis rbesides candida albicans.

Key words: Actinomyces, Denture, Stomatitis , Candida albicans

*Corresponding Author: Mandanakhatibi@yahoo.com

J Res Dent Sci. 2019; 16 (2) :102-109. 
خلاصه:

سابقه و هدف: استوماتيت ناشى از دنجر در •FF-G درصد از دارندگان دنجر رخ مى دهد. تا كنون علل مختلفى براى ايجاد آن

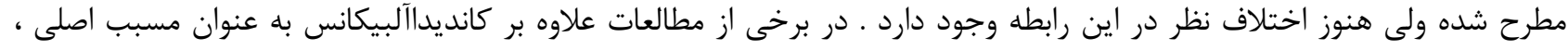

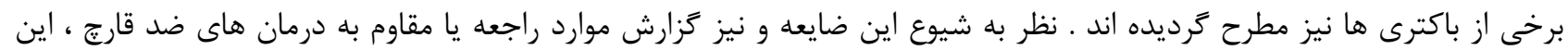

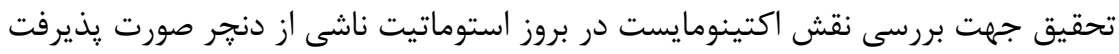

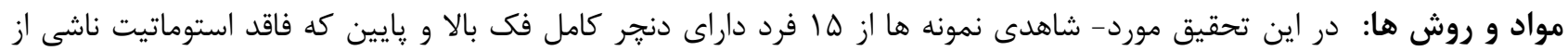

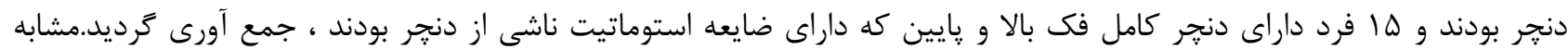

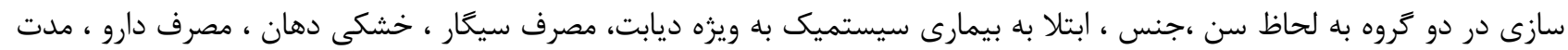

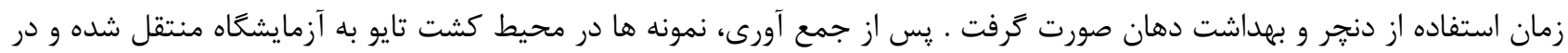

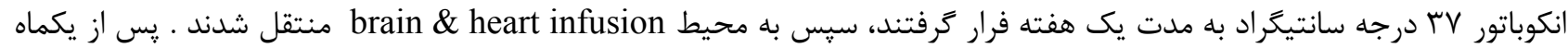

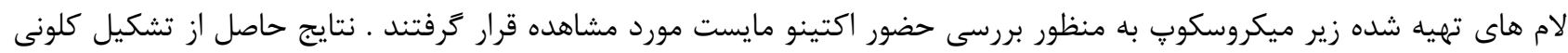

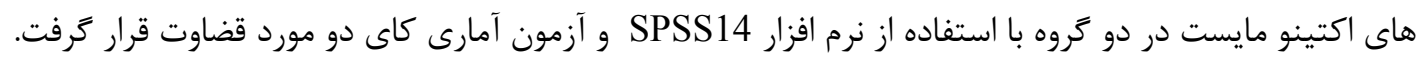

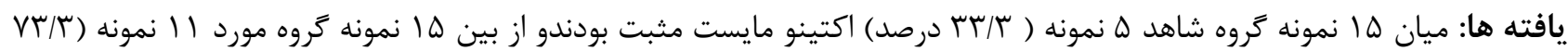

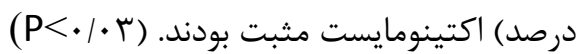

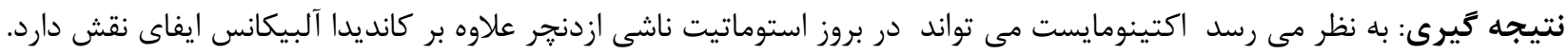

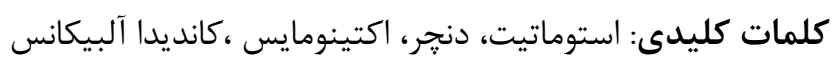

عليرغم نظر غلبه قارج ها در اتيولوزى ضايعه ،در برخى مطالعات جديدتر به غلبه باكترى ها بر قارج ها در ناحيه زيرين

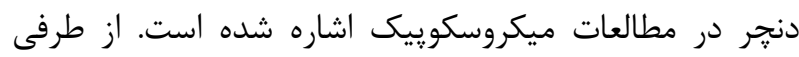

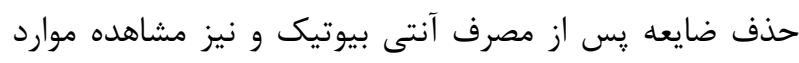
مقاوم به درمان ضد قارج بر نقش باكتريها در اين ضايعه تاكيد

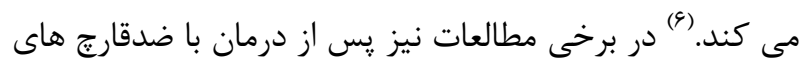

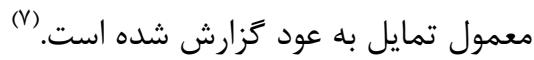
ميكروفلوراى موجود در ضايعات استوماتيت ناشى از دنجر ييجيده بوده و علاوه بر كانديدا آلبيكانس شامل باكترى هايى از Fونه هاى مختلف مانند استريتوكوكوس6ويونلا لاكتوباسيلوس - يره وتلا و اكتينومايست مى باشد. هنوز ميزان مشاركت و نقش باكترى ها در گِاتوزنز استوماتيت روشن نميباشد. (1) اكتينومايست باكترى گرم مثبت و فيلامنتوس بى هوازى و از ساكنين طبيعى حلق دهانى ، سيسته تنفسى فوقانى ، دستگاه
استوماتيت ناشى از دنجر به واكنش پاتولوزيك مخاط يوشاننده دست دندان مصنوعى (دنجر) در كام اطلاق مىشود. (') اين

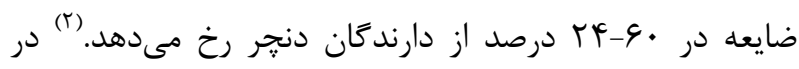
خانمها فراوانتر وبا افزايش سن شيوع آن بيشتر ميشود. تا كنون علل اتيولوزيكى مختلفى براى ايجاد ضايعه مطرح شده كه مرهم ترين آن كانديدآلبيكانس مىباشد. كانديدا آلبيكانس نوعى قارج گرم مثبت است كه به عنوان اركانيسم طبيعى محيط دهان افراد سالم شناخته ميشود. تحت شرايط خاص موضعى و سيستميك وابسته به ميزبان، اين قارج حالت ياتوزن مى يابد و ميتواند سبب برخى بيمارى ها از جمله

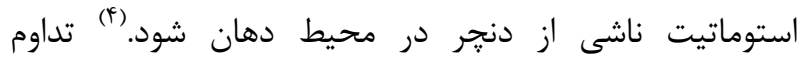
استوماتيت ناشى ازدنجر در صورت عدم درمان دارويى و رفع شرايط مستعدكننده منجر به ناتوانى بيمار در استفاده از دست دندان خواهد شد كه بر تغذيه و كيفيت زندگى او اثرگذار خواهد بود. (b) - (م) 
وخشكى دهان (1) با گروه مورد مشابه شده بودند، صورت

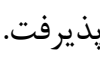

جامعه مورد بررسى (كروههاى مورد وشاهد ) ازميان مراجعه كنندكان به بخش بيماريهاى دهان وفك وصورت دانشكده دندانيزشكى دانشعَه آزاد اسلامى تهران كه يس از توجيه طرح موافقت آكاهانه وكتبى خود را جهت شركت در طرح و تهيه نمونه آزمايشى اعلام نمودند برگزيده شدند. يس از تعيين افراد واجدشرايط مطالعه واخذ رضايت نامه كتبى وتكميل فرم اطلاعاتى جهت نمونه گيرى يس از خشك نمودن ناحيه با كاز استريل توسط سواب ينبهاى از ناحيه كام بيمار وروى ضايعه، نمونه اى برداشته ودر محيط كشت تايو قرارداده شد. سيس از يك ناحيه سالم فاقد ضايعه درفك بالانيز يك نمونه برداشته و در محيط كشت تايو قرار گرفت. نواحى توسط كد مشخص واز يكديگرتفكيك شده وروى هرلوله آزمايش كد ناحيه وكدبيمار نوشته شد. سيس كليه نمونه ها به آزمايشعاه ميكروبيولوزى دانشكده يزشكى آزاداسلامى منتقل گرديد و بمدت Vاروز در انكوباتوردر دماى دV درجه سلسيوس

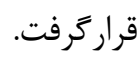

يس از مشاهده رشد باكتريها وايجادكولونى از محيطهاى كشت موجود، نمونهاى جهت انجام كشت هاى معمول بيهوازى شامل تايو و نمونهاى نيزجهت محيط كشت اختصاصى براى رشد اكتينومايست و رنغ آميزى گرم برداشته شد. پس از حدود يك ليك ماه براى بررسى رشد اكتينومايستهاى احتمالى كلونيهاى

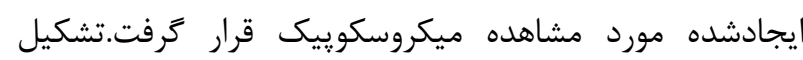
كولونى بعنوان معيار حضور يا عدم حضور اكتينومايست مورد توجه قرار گرفت. لازم بذكراست يس از قراركيرى نمونه ها درمحيط كشت تايو دريوش گِنبه اى روى لوله آزمايش قرار گرفت و با جسب يارافين سيل شد و دركمتر از أ ساعت هرنمونه به آزمايشعاه منتقل مى گرديد. همجنين محل برداشت نمونه دريرونده بيمار قيد شده وكدبيمار روى لوله آزمايش حاوى محيط كشت ثبت مى گرديد.هنگام نمونه گيرى به ازاى هرنمونه كه درگروه مورد
Fوارش و سيستم تناسلى خانمها ميباشد. ايزولاسيون و تشخيص آن با روشهاى معمول ، مشكل و صرفا بر اساس برخى از مشخصات بيوشيميايى مثل پيڤمانتاسيون و توليد كاتالاز انجام مى پذيرد.ويرولانس اركانيسم ، پيايين ويك باكترى

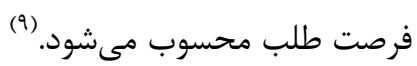
نقش اكتينومايست در بروز ضايعات يرى إيكال مقاوم به درمان هاى معمول ريشه دندان، يوسيدگى هاى دندانى و پاكت هاى

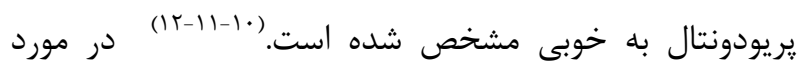
بررسى نقش آن در استوماتيت ناشى از دنجر نيز تحقيقات محدودى صورت كرفته (8،با) ولى هنوز خلاء اطلاعاتى در مورد نقش آن احساس ميگردد. اين امر همراه با نياز به درمان هاى طولانى مدت ضدقارج در برخى از بيماران و ززارش موارد عودكننده و مقاوم به درمان ، محققين اين مطالعه را برآن داشت تا به رابطه اكتينومايست با استوماتيت ناشى از دنجر را در مراجعين به دانشكده دندانيزشكى آزاد اسلامى تهران بررسى كنند،، شايد نتايج تحقيق بتواند منجر به تغيير يروتكل درمانى ضايعه و بهبود شرايط مبتلايان گردد.

\section{مواد و روش ها:}

اين مطالعه مورد-شاهدى برروى گروه موردشامل ها فرد بى دندان كامل كه از دنجر هردوفى استفاده مى كردند ومدت استفاده از دنجر فك بالاى آنان بيش از يكماه بود ومبتلا به استوماتيت ناشى از دنجر بودندبا معيار تشخيصى طبقه بندى

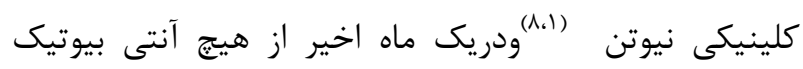
ودهانشويه وداروى ضدقارج استفاده نكرده بودند وگروه شاهد ها نفرى شامل افرادى كه داراى دنجرهردوفى بوده ومبتلا به استوماتيت ناشى از دنجر نبودندودريك ماه اخير از آنتى بيوتيك ودهانشويه وداروى ضد قارج استفاده نكرده واز لحاظ سن، جنس، مصرف هرگونه داروجز آنتى بيوتيك ودهانشويه وضد قارج، ابتلا به بيمارى سيستميك خاص بويزه ديابت،طول

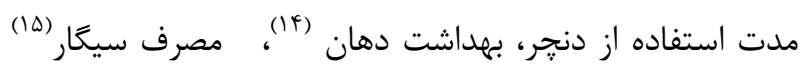


بزار تعيين سايرفاكتورهاى مشابه سازى يرسش از بيمار

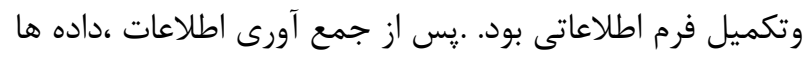

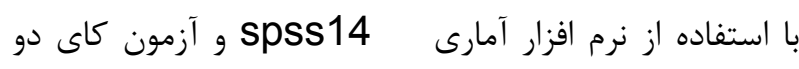
تحت آناليز آمارى قراركرفت.

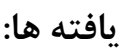

توزيع خصوصيات مورد بررسى گروه هاى مورد و شاهد كه در

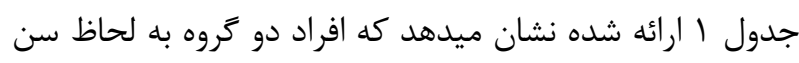

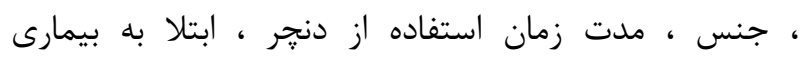
سيستميك خاص ، مصرف سيكار ، بهداشت دهان، مصرف دارو

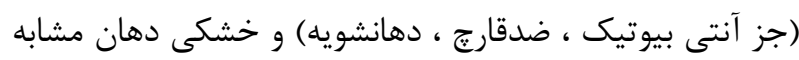

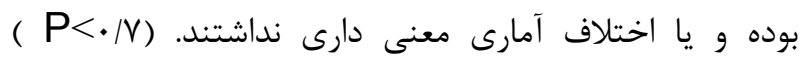

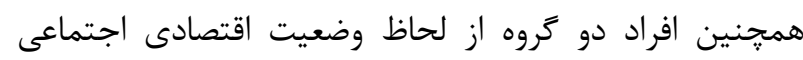
(مراجعين به يك مركز ) و همزمانى نيز مشابه بودند.
قرار ميكرفت يك نمونه مشابه براى گروه شاهد انتخاب ميشد(براساس معيارهاى مشابه سازى). بدين ترتيب اخر براى

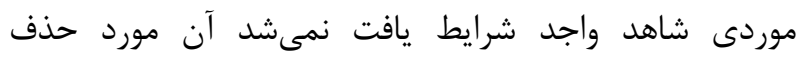

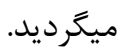

براى تعيين خشكى دهان اندازه گيرى بزاق غير تحريكى ملاك

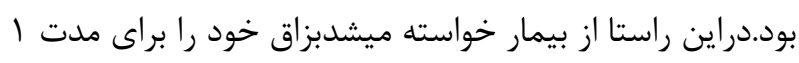

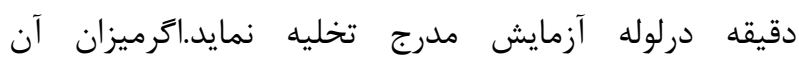
كمتراز //ميلى ليتر دردقيقه بودبعنوان كزروستوميا در نظر مران كرفته ميشد. (1) جهت تعيين وضعيت بهداشت دهان در افراد بى دندان مشاهده يلاك ورنگدانه روى سطح يوشاننده ناحيه بى دندانى

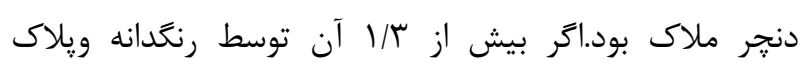

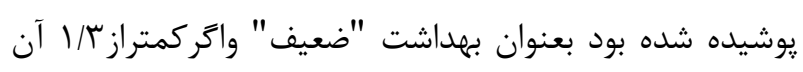

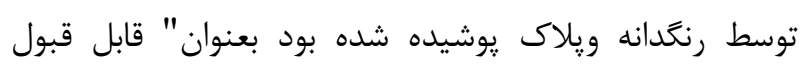

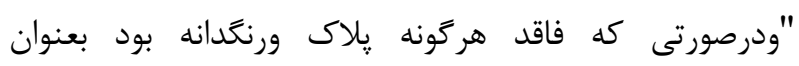

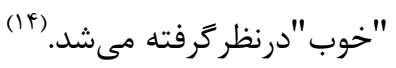

جدول ا- توزيع افراد مورد بررسى بر حسب خصوصيات به تفكيك وجود يا عدم وجود ضايعه

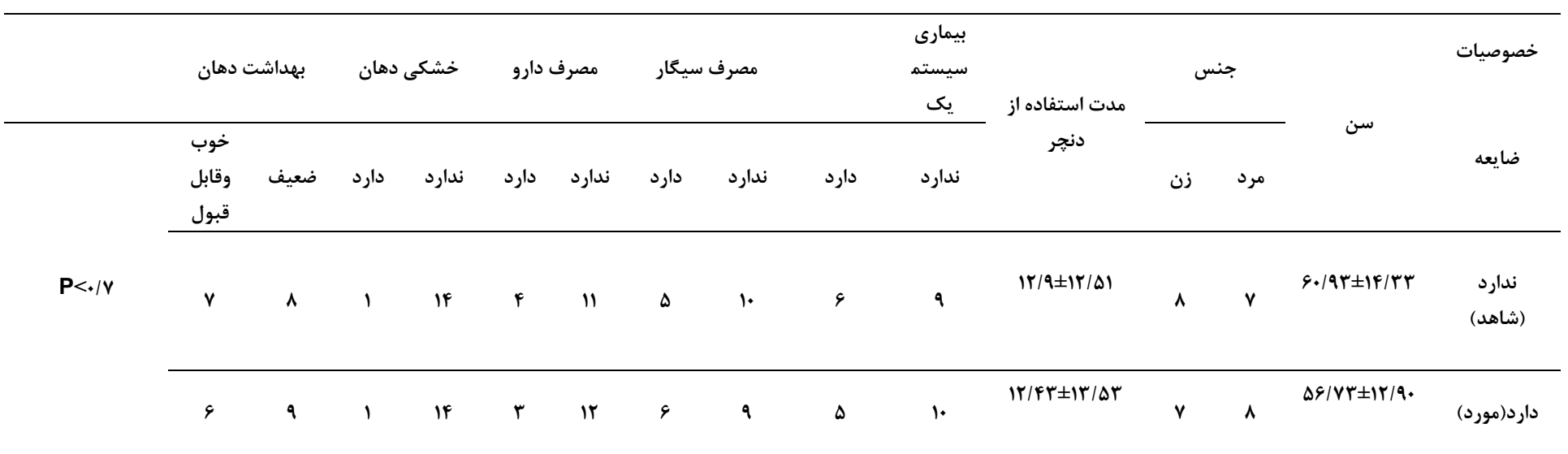

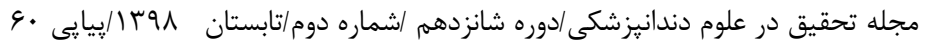


همجنين تحقيق Daniluk وهمكاران نشان دادكه تداخل بين قارج وباكترى دربروز ضايعات ناشى ازدنجردخالت دارد.دراين تحقيق اكتينومايستها بعنوان باكترى بيهوازى از دازين ضايعات جداشدند. (r) Glass دنجر جدا كردند. (ז') يزوهشهاى اخيربه نقش باكتريها بويزه اكتينومايست در بروز

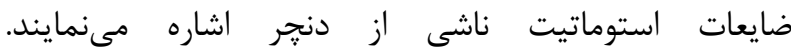
يافتهاى تحقيق حاضر نيزدرراستاى تاييد اين يزوهش ها

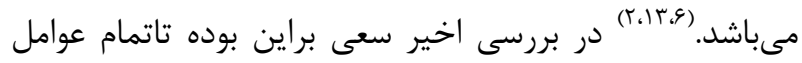

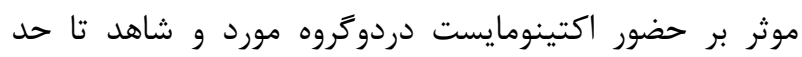
امكان حذف يا مشابه سازى گردند از جمله سن، جنس، مدت درد

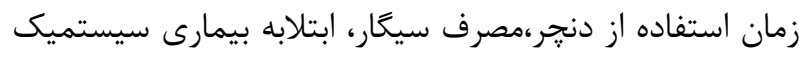

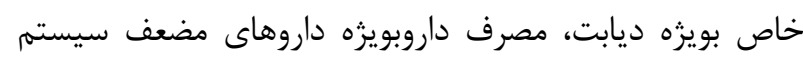
ايمنى، خشكى دهان و بهداشت دهان. بررسى اثر مجموعه اين عوامل درهيجيك از مطالعات كذشته لحاظ نكرديده بود. درتوجيه تحقيق حاضر و مشابه سازى خشكى دهان دردوگروه بايدتوجه داشت كه عوامل مرتبط با از دست دادن دندانها عبارتند از يوسيدكيهاى شديد، از دست دادن سايورت

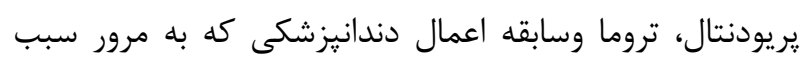

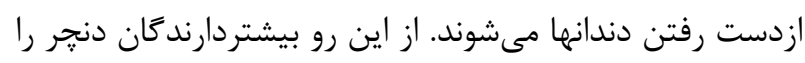

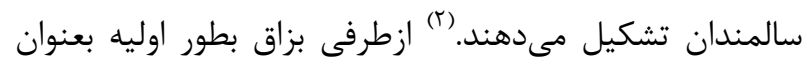
عامل شستشوى باكتريها در دهان عمل مى كند و آكلوتينين نيز

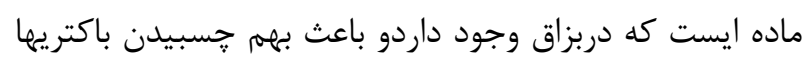
ميشودوازجسبندگى آنها به مخاط جلوكيرى كرده و سبب دفع يا كاهش كلونيهاى باكتريال دردهان مىشود. (iv)

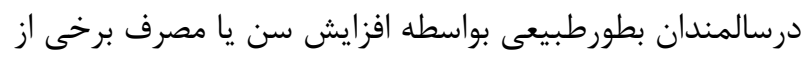

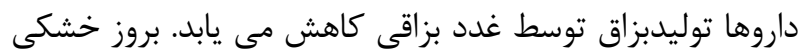
دهان مىتواند بعنوان عاملى جهت تجمع بيشتر اركانيسمها

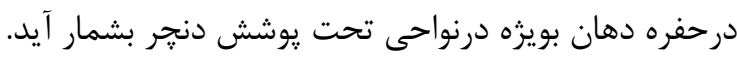

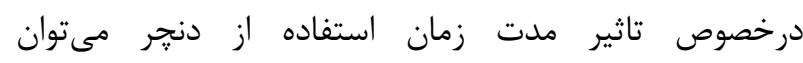

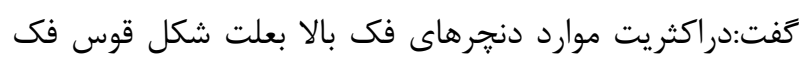

توزيع افراد مورد بررسى بر حسب استوماتيت ناشى از دنجر و

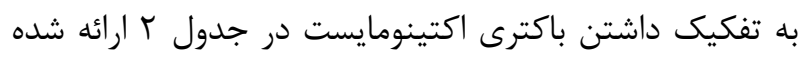

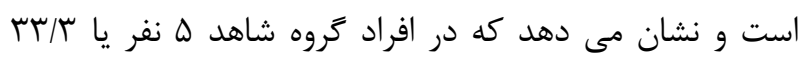

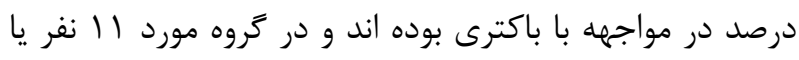
آ

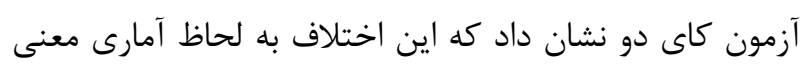

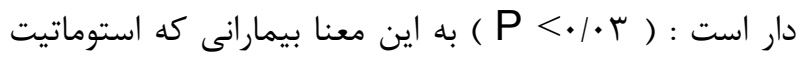
ناشى از دنجر داشتند ه/ه برابر بيشتر از افراد فاقد استوماتيت

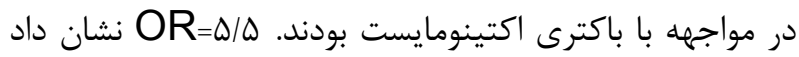
كه اين مواجهه بيشتر ، به لحاظ تعميم يذيرى نيز قابل قبول

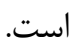

\begin{tabular}{|c|c|c|}
\hline \multicolumn{3}{|c|}{ جدول - توزيع افراد مورد بررسى بر حسب ابتلا به استوماتيت } \\
\hline \multirow[t]{2}{*}{ 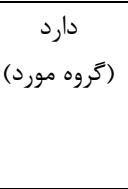 } & 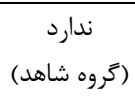 & 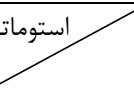 \\
\hline & & اكتينومايست \\
\hline$r \varphi(F)$ & $99(1 \cdot):$ & عدم حضور \\
\hline$V F(11)$ & $r F(\Delta)$ & حضور \\
\hline $1 \cdots(\mid \Delta)$ & $1 \cdots(1 \Delta)$ & جمع \\
\hline
\end{tabular}

تحقيق حاضرنشان دادمبتلايان به استوماتيت ناشى از دنجر درمواجها بيشترى با باكترى اكتينومايست هستند. Martins داراى استوماتيت ناشى از دنجركوكسى هاورادهاى كرم مثبت بيشترازافرادداراى دنجركامل وفاقد استوماتيت مشاهده مى شود. وهمكاران نيز وجوديلاك ميكروبى حاوى باكتر يهاى Salerno

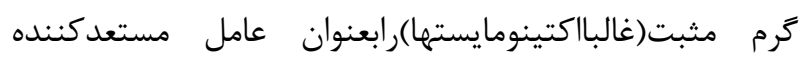
استوماتيت ناشى از دنجر مطرح كردند. (^) 
مرورى بر مقالاتى كه عوامل دخيل در بروز استوماتيت رابررسى

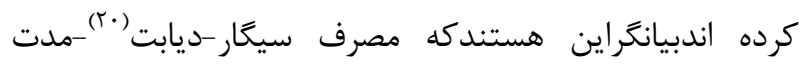
زمان طولانى استفاده ازدنجر بنوعى سبب آسيب واختلال درنحوه عملكردطبيعى إيتيلوم مى گردند. (if) بدنبال آسيب به سدمخاطى، باكتريها وقارجها بسرعت به نواحى عمقى تر نفوذ كرده و سبب بروز بيمارى ميگردند.علاوه برديابت-بهداشت دهان- ميزان بزاق، مصرف سيگار و دارو، نقص برخى از عوامل تغذيه ایى ودرَيرى كليه (بعنوان يك بيمارى سيستميك خاص)ونيزسطح ويتامين A خون بعنوان عوامل دخيل بروز استوماتيت ناشى از دنجر ززارش شده اند. (T. (T) لازم به يادآورى است كه محققين دريك بررسى متا آناليز بر روى شيوه درمانى گَناگون دنجراستوماتيت ازنظرعلايم بالينى وميزان تجمع ميكروب تفاوتى ميان روشهاى درمانى ضدعفونى كننده وضدقارج نيافتندوتوجه به اركانيسمهاى دخيل ديخرجزقارج هاراضرورى دانستند. (Iان) همجنين ييشرفتهاى اخيربربكارگيرى موادمورد استفاده

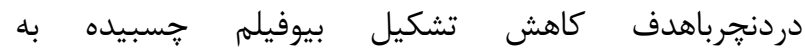
دنجرمتمركزشده اندتاكلونيزاسيون قارجى وباكتريال كاهش يابدو همراه با رعايت دقيق بهداشت دهانى به كاهش فراوانى

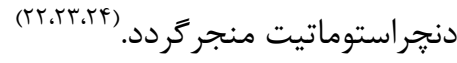
با توجه به مشابه سازى دو گروه مورد و شاهد دربررسى حاضر A تنها بررسى دقيق نواقص تغذيه اى ينهان و سطح ويتامين خون كه تظاهربالينى خاص ايجاد نكرده باشد قابل اجرا نبود(بدليل لزوم انجام آزمايشات يارا كلينيكى متعدد و متنوع

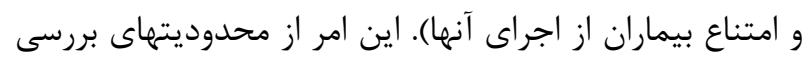
محسوب مىشد. ضمنا ياسخهاى فردى ميزبان و جَّونگى ياسخهاى ايمنى اوليه و اكتسابى هر فرد از جهت كمى وكيفى نيز ميتواند عامل مهمى در ميزان تجمع اركانيسمها بويزه اكتينومايست قلمداد شود. باتوجه به استريل بودن محيطهاى كشت وسوابهاى گينبه اى نمونه بردارى وانتقال هرجه سريعتر به آزمايشعاه درتحقيق
بالا ووسعت استخوان كام از سيل(يوشش) مخاطى مناسبى برخوردارندودرصورتى كه به مدت طولانى درطول شبانه روزازدهان خارج نشوندميتوانندمانع رسيدن بزاق به سطح زيرين دنجر شوند. ازطرفى دنجرفى يايين بعلت فرم نعل اسبى شكل فك يايين وعضلات كف دهان مانند دنجر فك بالا قادر به يوشش مخاط در برابر ورود بزاق نمىباشد. (1) نرسيدن بزاق به سطح زيرين دنجر ميتواند محيط مناسبى براى رشد باكتريهاى بيهوازى فراهم كند.علاوه برنقش بزاق دربروز ضايعه وفراوانى اركانيسمهاى دخيل حضور دنجر به مرور زمان باعث ايجاد تغييراتى درمخاط طبيعى دهان مىشود. طبق تحقيقات بعمل آمده درمخاطى كه تحت يوشش دنجر قرار نداردبا افزايش سن ضخامت اييتليوم افزايش مى يابدولى بنظر ميرسد استفاده مداوم از دنجر باعث شود كه اين افزايش ضخامت رخ ندهد. تغييرنوع إيتليوم از ارتوكراتينيزه كامل به ارتوكراتينيزه ناكامل درنواحى يوشيده شده توسط دنجر كه اغلب پيس ازيكسال استفاده از دنجر رخ ميدهدنيز گزارش شده كه توجيهى درمسيرمقاومت كمتر مخاط در مقابل نفوذ اركانيسمها مىباشد. (1) (م) حضوردنجربراى مدت طولانى وبى وقفه درحفره دهان طى شبانه روز اجازه استراحت وانجام فعل و انفعالات طبيعى با لبع بزاق و محيط را ازمخاط زيرين مى گيرد. ازسويى ديگردهان محيطى كاملا باز وقابل دسترسى براى اركانيسمها مىباشد. باكتريها نيز براى بقاء وكلونيزاسيون بايستى ابتدابه مخاط اتصال ييداكنند و اين عمل بين باكتريها بصورت كاملا انتخابى رخ مىدهد. برخى از ميكرواركانيسمها دراين ميان بعنوان ياتورن فرصت طلب عمل ميكننديعنى زمانى كه به هر علتى آسيب به سد دفاعى مخاط وارد شودواردعمل شده و ايجاد آسيب مخاطى

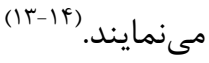


البته باوجوداحتمال ه/هبرابرى مواجهه با اكتينومايست در

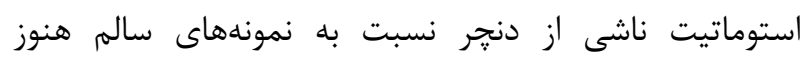
نميتوان نقش قطعى اتيولوزيك براى اكتينومايست دراين ضايعه قائل شد. اين نتيجه گيرى قطعى نياز به تحقيقات گسترده

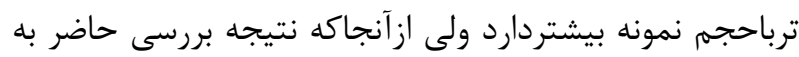
لحاظ آمارى تعميم يذيرى قابل قبولى داشته شايدبتواند راهخشاى يزوهشهاى آينده وطراحى درمانهاى جديد ضدميكروبى همراه با درمانهاى ضدقارج درموارددرمان استوماتيت ناشى از دنجر بخصوص موارد مقاوم به درمانهاى

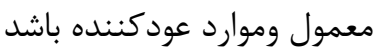

حاضر سعى بر اين بودكه احتمال آلودگى ثانويه نمونه هابه

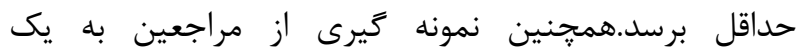
مركز(دانشكده دندانيزشكى آزاداسلامى)باعث شده جامعه مورد بررسى از نظر شرايط اقتصادى-اجتماعى وهمزمانى نسبتا

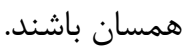
مجموعه عوامل يادشده از مزاياى مطالعه اخير ودراستاى

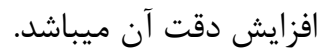
نتيجه كَيرى: به نظر ميرسد اكتينومايست مى تواند در بروز استوماتيت ناشى مئى ازدنجر علاوه بر كانديدا آلبيكانس ايفاى نقش نمايد. 


\section{References:}

1.Zarb J، Bolender C . Prosthodontic treatment for edentulous patients at complete dentures and implant supported prosthesis; 13 nd ed. Philadelphia: Mosbey. (4) 2012. p:34-36

2.Daniluk T ،Fiedoruk K، Sciepuk M، Zaremba ML.

Rozkiewicz D, Cylwik-Rokicka D, et al . Aerobic bacteria in the oral cavity of patients with removable dentures. Advances in medical science 2006 ;51 (1):8690

3. Mravak M، Hemerich L،Jurcis I Jeolimov V.Stimulating local factors in the development of denture stomatitis. Acta stomatal croat 2000 (3):133-6.

4. Salerno C، Pascal M. Contaldo M. Esposito V, Maurizio Busciolano, Lucio Milillo et al. Candida associated denture stomatitis. J of medical oral patol oral cir buccal 2010; (2):1-5

5.Sciubba J. Denture stomatitis treatment and management.2015; Available at:

https:/emedicine.medscape.com/article/1075994-

treatment . september 2; 2015

6.Martins $\mathrm{KV}$, Gontigo SM,Treatment of denture stomatitis:literature review.Rev Bras odontol 2017; 74(3):215-220

7.Chandra J، Mukherjee P.K، Leidich S.D. Faddoul FF, Hoyer LL, Douglas LJ. Antifungul resistance of candidial biofilms formed on denture acrylic in vitro. Journal of dental research 2001; 80(3):903-8.

8.Greenberg MS، Glick M ،Ship J. Burket's oral medicine.2008.11nd ed.BC Decker Inc.Hamilton.chapter(4):81

9. Simmer PJ. Doerv KA.Steinmetz LK. Wengenak NL. Mycobacterium and aerobic Actinomyces culture:Are two medium types and extended incubation times necessary?

J clin Microbial 2016;54(4):1089-93.

10.Santos Al.Siqueira JF.Rocas IN.Jesus EC.Rosado AS.Tiedje JM. Comparing the bacterial diversity of acute and chronic dental root canal infections. J PLOS one $2011 ; 6(11): 1-8$

11. Micheal G.Newman M.Takeie H.Fermin A.Carranza

F.Carranza's clinical periodontology, 12 nd ed. By Elsevier Canada 2015 (23) : 232، 244،64.

12. Asikainen S.Dogas B.Turgut Z.Paster BJ.Budur A.Oscarsson J. Specified species in gingival crevicular fluid predict bacterial diversity. J PLOS one 2010;25(5) $: 1-12$
13.Glass RT. Hadley CS. Conrad RS. Partial spectrum of microorganism found in denture and possible disease implication. JAOA 2001; 101(2):92-4.

14. Naik AV, Pai CR. A study of factors contributing to denture stomatitis in a north Indian community. Int $\mathbf{J}$ Dent ;2011:589064.

15. Khatibi M.Ghavamzadeh A.Farizadfar M.Khalifeh $\mathrm{S}$. The prevalence of oral mucositis and related factors in 80 BMT patients in Tehran shariati Hospital. JSSU 2015 ; 23(2):1886-88.

16. Glick M. Burkets oral medicine. 12 nd ed. Shelton,Connecticut; Peoples medical publishing house USA; 2015 (8):194

17.Howard F. Lamont R. Jenkinson H. Oral microbiology at a glance.1th ed. , Southern Gate, Chichester, West Sussex; united kingdom; John Wiley \& Sons Ltd pub;2010. p:9,66

18-Baochen Sh. Tingxi Wu. Jeffrey M. Anna E. Youngik Y. Xuesong H. Hongyang Lv . Xuedong Z. Wenyuan Shi. Huiying Li. Renate L. The DentureAssociated Oral Microbiome in Health and Stomatitis. 2016; Available at: https://msphere.asm.org/content/1/6/e00215-16 December $28 ; 2016$

19.Lindsay E .Robertson D .Nile C. Cross J.The oral microbiome of denture wearers is influenced by levels of natural dentition. J Plos one 2015; 1-22

20.Khatibi M .Amirzadeh Z .Heidari I .Estifaee A .Examining the relationship between type2 diabetes with denture stomatitis.J Apple.Biol.Sci 2015; 5(12):284-7.

21.Yarborough A .Dugum I .Mendonca G. Macgraw $\mathrm{K}$. Stoner L. Evidence regarding the treatment of denture stomatitis . Journal of Prosthodontics 2016;(25):288-301 22. Pathmashri V.P Abirami D. A review on denture stomatitis. J .Pharm.sci \&Res 2018 ;8(8):875-7.

23.O, Donell LE.Alalvan HK. Kean R. Calvert G. Nile CJ. Candida albicans biofilm does not influence denture stomatitis but strongly influence denture cleansing capacity. JMed microbial 2017; 66(1):54-60

24. Flores IL.Souza LT. Is topical Antifungal the appropriate first choice for denture stomatitis ?Ann clin lab Res.2017(5):1-5

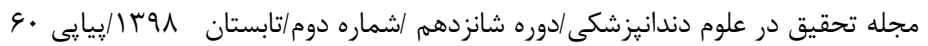

